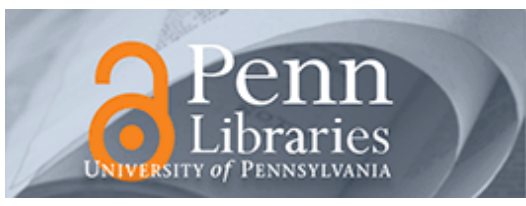

University of Pennsylvania ScholarlyCommons

Department of Anthropology Papers

Department of Anthropology

1963

\title{
The Function of Religion in Persian Society
}

Brian Spooner

University of Pennsylvania, spooner@sas.upenn.edu

Follow this and additional works at: http://repository.upenn.edu/anthro_papers

Part of the Anthropology Commons

\section{Recommended Citation}

Spooner, B. (1963). The Function of Religion in Persian Society. Iran, 1 83-95. Retrieved from http://repository.upenn.edu/ anthro_papers/139

This paper is posted at ScholarlyCommons. http://repository.upenn.edu/anthro_papers/139

For more information, please contact libraryrepository@pobox.upenn.edu. 


\title{
The Function of Religion in Persian Society
}

\author{
Abstract \\ of Persia between 1959 and 1962. \\ Disciplines \\ Anthropology | Social and Behavioral Sciences
}

Observations on the religious aspect of rural life made during residence and travel in the north, east and south 


\title{
THE FUNGTION OF RELIGION IN PERSIAN SOGIETY ${ }^{1}$
}

\author{
By B. J. Spooner
}

Observations on the religious aspect of rural life made during periods of residence and travel in the north, east and south of Persia between I959 and I962.

\section{Areas Visited}

Main periods of residence during the above period were within the limits of the bakhsh of Jajarm and the shahrestān of Gunābād in Khorāsān. A short period has also been spent in the villages around Lasht e Neshā in Gilān. Otherwise the main route of survey has been southwards from Gunābād, through Qā'enāt (including Asadābād to the east and Khūsf and Khor to the west), Sistān and Balūchistān, to the coast and Dashtiāri in the Makrān; thence westwards along the coastal plain through Chāhbahār, the mobile villages of Kahỉr and Bir, Bāndinnī, Jāsk, Sỉrỉk, Kūhestāk, Mĩnāb, Bandar Abbās, and through the Banāder as far as Bushire; thence to Shîrāz and across country through Nairizz and Sírjān to Kermān and Bam; and lastly, north-west from Bam to Gūk and Shahdād (formerly Khabiss), north-east across the Lūt to Fedeshk and Knor, north-west again through Dihūk to Tabas and down to Yazd.

\section{Purpose}

The purpose of the journey was to observe the practice of the established or majority religion of each particular area-generally the Ja'farī Shi'a, but Sunnī, for example, in Balūchistān. Little attention was paid to sects and creeds outside the pale of the majority religion of a particular area, or to cities and large towns where official religious teaching, politico-religious considerations, or " akkhund$b \bar{a} z \bar{i} "$, might influence the religion of the ordinary people unduly. The intention was to study the majority religion in its own community as unaffected as possible by foreign and modern influences and alien contacts, i.e. in conditions where it was not self-conscious, and thereby to make a contribution to the study of Persian society at large by an attempt to see the function of the religion within it.

\section{The Mosque and the Mulla}

The average Muslim community is perhaps generally pictured as being centred, religiously if not socially, on the local mosque. The situation in the following villages, whose populations range from approximately 6,000 in Jajjarm to as little as 500 in some of the villages around Lasht e Neshā, may serve as a guide to the validity of this impression.

(i) Jājarm has a total of eight mosques, built mainly in the last century or earlier when the district was apparently much more prosperous. Only one is now in regular use. Most of the remainder are in various stages of ruin. The community is served by three resident mullās, two of whom are native.

(ii) Mehné, which is rather smaller, has two mosques, but no resident mullā.

(iii) Khor has one mosque and one resident mullā.

(iv) In the district of Lasht e Neshā in Gilān not one of five villages visited had a resident mullā, though each community had its mosque. ${ }^{2}$ According to the local people there had been mullās there until five years ago, but, owing to a drop in the standard of living due to the shortage of water, the people were no longer able to support them, and they had gone elsewhere.

\footnotetext{
1 The method used in the transliteration of names and technical terms in this article is designed to represent modern Persian pronunciation, this being considered by the
}

author to be more suited to the nature of the article.-Editor

2 The village mosque in this area, however, is without a mihräb, and is known not as a mosque, but as a tekyé. Cf. footnote 25 . 


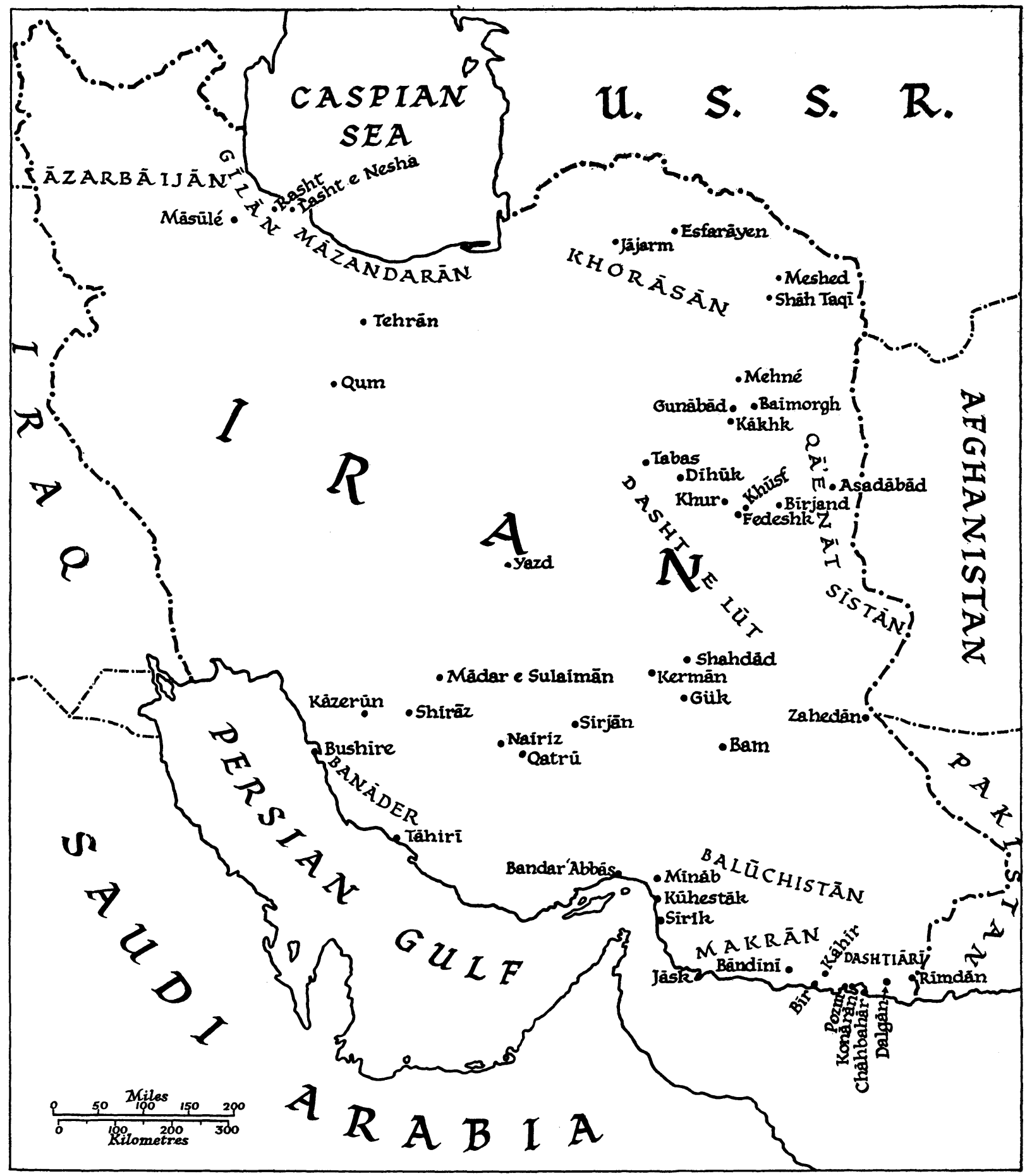

Fig. I. Map of Iran showing location of places mentioned in the accompanying article. 
However, in periods of particular religious significance, such as Ramazān and Muharram, all villages (except the very smallest), both those with resident mullās and those without, appear to receive visits from mullās and tulläb3 from the towns.

Where there are no mullās there may be a darvish, a du' $\bar{a}$ neviss, or a qur'ān-khān. At least somewhere within tolerably easy reach there will normally be someone with some form of religious designation. The $d u^{6} \bar{a}$ nevis writes charms; the qur'an-khän, though probably illiterate, chants passages from the Qur'ān at funerals, and is often mordeh shür as well-he washes the dead. The darvish has claims to mysticism and may be of no fixed abode. There may be friction between him and any mullās. There is usually something mysterious about the darvish, and mystery always attracts the ordinary man in the hope that it may be a short cut to divine favour. ${ }^{4}$

Finally there are the sayyids, descendants of the Prophet, who would appear to fulfil no particular function in the life of the community, except in so far as their presence is a continual reminder to the community of the relevance of the Prophet and Islam to them. The sayyid is a more valuable specimen of humanity, for he is dearer to the Prophet than his fellows, ceteris paribus. Therefore, a man who had a sayyid as a servant would feel guilty if he beat him. Kindness to a poor sayyid carries with it a special $s a v \bar{a} b$, and poor sayyids may be chosen to carry out various ceremonies connected with averting the evil eye, ${ }^{5}$ and other religious or quasi-religious functions.

There is, of course, no official clergy in Islam. There is no closely knit hierarchical organization which it would be possible to refer to, in comparison with European situations, as "The Church". Many villages-even quite large ones-do not have mullās. However, in the normal village, which does have one or more, the mullā may have land, and so a private income, or may work, but would more normally live off the community and many communities are too poor to support them. In Jājarm it was estimated that the two mullās who, practically speaking, live off the community receive about $\mathrm{I}, 000$ tömanns per year each from the people, ${ }^{6}$ though it is doubtful whether the estimate is reliable. Normaily the mullā will belong socially to the lower strata of society. He will have received more formal education than his neighbours, but this will normally have been limited to the study of the Qur'ān and cognate subjects. His position in his community will depend more on his personal qualities than custom or precedent, but whatever his personal qualities he will tend to start at a disadvantage, for he is, either more or less, a parasite. His ex officio activities include a khutbé or sermon in the mosque on Fridays, reading rōzé $e^{7}$ as required, and officiating at weddings, etc. Outside these functions he may be despised or he may be respected, he may be a man of considerable social power (through ownership of land or family connections) or he may not. He may be quite enlightened and scholarly with a genuine interest in and knowledge of the history of his locality. He may spend a large amount of his time in a pedantic study of Arabic, Islamic tomes.

In proportion to the amount of respect and social power he enjoys, he may bring the generality of the local population closer to, and make them more dependent on, the religion of the mosque and the historical principles and tradition of Shi'ite Islam. For the most conspicuous religious act in the life of the community is, of course, the regular, set prayers. The illiterate peasant has little idea of their meaning, but this is not important. The important thing is that, in the first place, at intervals throughout the day they direct the believer's attention towards his God and the religion he confesses, and, secondly, by punctuating the day and the day's work for him-as sunrise, noon and sunset, they become an integral part of daily life. In Shi'ite Islam these prayers need never be corporate, and there is no compulsion to attend the mosque, even on Fridays. One result of this is that in the ordinary Shi' a village the mosque is often a prestige building rather than a religious functional necessity, and is

3 Theological students.

- In the East of Persia the term darvish is applied to occasional wandering mendicants with religious pretensions and little or no connection with the official religion; while the term süf $i$ denotes the follower of a particular tariqat-generally the one in Gunābād.

${ }^{5}$ See below "The Evil Eye".

- $£ 47$ ros.

" See below " Rozé-khānì ”. 
regularly attended only by the old people and the excessively devout. Any improvement on this congregation depends on the personal qualities of the preaching mulla. In these circumstances the mosque tends to function as the symbol of the religious persuasion of the village-of the fact that it is a Muslim village. And for this reason the community as a whole is conscious of a duty towards the upkeep of the mosque. Now the respected, powerful, capable mullā may make full and efficient use of this type of consciousness in the community, attract them more and more to the mosque by his preaching, and consequently perhaps raise their moral and religious standards by appeal to the religious law of Islam. So the mulla who is really good at his job has it within his power to focus the religious attention of the community on the mosque and the strict, traditional religion of rules for which it stands.

It would appear that this situation does not occur over frequently to any conspicuous degree. But the mulla (supported perhaps by the häjjis) will be the only power in the village to attract the community in this direction. He will seldom have much obvious connection with the local shrine, and the conflict between the two directions is sometimes quite patent. For instance, in the architectural plan of the village the mosque may occupy a more peripheral site or the shrine may be by far the more sumptuous and conspicuous building. ${ }^{8}$

It may be that the main importance of the mosque is that it provides a place for assembly and a pulpit from which the community may be corporately taught. For outside the mosque there is no provision for any corporate activity above the level of the family and the personal relationship pattern. ${ }^{9}$ And attendance at the mosque is optional. In Islam all believers are essentially equal before God. In the Shi'a, which has no prescribed provision for corporate activity, religion becomes essentially private, and the importance of the personal relationship ${ }^{9}$ in the social structure is emphasized.

Rōzé-khänī, Saväb, Du'ā, Nazr

The following are religious functions and terms which may be considered essential parts of the ritual and practised religion, but which have no defined connections with the mosque-the official house of worship.

The rōzé-khäni can best be described as an intoned exposition or interpretation, by one practised in the art, of the general faith, of which the climax and major part will be concerned with the passion and death of Husain, ${ }^{10}$ or some related aspect of the Muharam story. It is calculated to arouse the emotions of the gathered faithful, who will weep profusely (as they would in ordinary mourning). It may last as little as ten minutes or as much as an hour. Those who gather round to hear the recital, which can be moving in the extreme, in fact rehearse their faith and deepen their sympathy with Husain and his companions in their suffering, and thereby gain a saväb, i.e. become eligible for a spiritual reward in heaven.

This is, of course, only one method of obtaining a savāb. Another obvious way is the ordinary good turn, particularly in respect of the poor and orphans. Savāb is the exact opposite of gunäh: sin.

The term $d u^{c} \bar{a}$ may be understood in the same sense as the popular use of the word prayer in English, and the term nazr may be translated vow. The believer will make a $d u^{6} \bar{a}$-prayer for something -and at the same time will make a nazr-will vow - that if the prayer be fulfilled, he will, for instance, make the pilgrimage to Kerbalā, or finance so many rōzé-khānī.

\footnotetext{
${ }^{8}$ E.g. Māsūlé in Gīlān.

- In Persia, society is bound together almost exclusively by the personal relationship, which takes the form of a deep, unquestioningly loyal friendship and provides the links between families, which are the basic units of society. The only thing a man can definitely rely on outside his own family circle is such a friendship, which naturally becomes the more intense because of the greater need of social security, which in a western society is provided rather by institutions and a relatively sovereign respect for the law.

The relationship within the family itself is less secure: a senior member will expect a definite display of respect from any member junior to him. For instance, the junior member must be the first to greet, otherwise no greeting will take place. A
}

son will not smoke in the presence of his father, or even of his elder brother. Each member of the family seems to feel he has to insist on constant recognition of his status for the sake of his personal security.

Outside these two types of relationship all relations between individuals are governed by a comprehensive system of verbal and behavioural etiquette, known as ta a aruf (this is far more sovereign than its western counterpart, because of the greater need for it), the aim and function of which is to eliminate surface friction in social relations and prevent the loss of "face".

10 The Third Imām and Prince of Martyrs who died on the field of Kerbalā. See below "Days of especial religious significance in the yearly cycle". 
Sin (gunäh)

The conception of sin in Persian rural society is closely linked with the norm in outward conduct. Inward things are little concerned. Love has nothing to do with it. A man is much freer than, say, his Christian counterpart, who, however hard he tries, knows he has no hope of living quite as he ought. He must live by the law of the Qur'ān and the Prophet. He must pray in certain ways at certain times; he must fast in Ramazān; and, being Shi'a, he must be filled with sympathy for Husain and identify himself with the " party" of the Holy Family. In the law he is not asked to do anything unreasonable. Everything is quite logical and moderate. He is never required to forego his pride and turn the other cheek, or love his enemy. ${ }^{11}$ And if he keeps the law he goes to paradise, i.e. he is not a sinner. There is no original sin to impede his progress.

The most important sin for the ordinary Shi'a villager is that he or she should fall behind in prayer or fasting-should fail in the obvious routine of the law. It is the only thing responsibility for which would never be attributed to destiny (sar nevesht). For it is the one thing which depends on the individual, with no reference to the particular community he lives in.

\section{The Foregiveness of Sins: Shrines and Pilgrimage}

A Shi'a Muslim, who feels he is guilty of sin, of not living as God through his Prophet and the Qur'ān informed him that he should, must place his hope in finding favour with the Imāms and "saints", who will then intercede for him with God at the Resurrection. Even if he is not particularly conscious of sin, he will, if he is devout, seek the favour of the Imāms and visit their shrines, simply for the sake of the love he has and knows he should have for them, for they are nearer to God than he himself can ever be. Some of these shrines have a universal appeal, e.g. that of the Imām Rezā at Meshed, his sister Fātemé at Qum, and Husain at Kerbalā. Then there are a multitude of localized sons and relatives of Imāms and holy men, known and reverenced only in small particular districts and villages, where modest shrines have been constructed for them over their tombs.

The normal means of obtaining the favour required is pilgrimage. The main pilgrimage in Islam is, of course, the hajj, the pilgrimage to Mecca, which is enjoined once in a lifetime on all the faithful with the means to perform it. But, perhaps because of this proviso, and the means required for the journey from Persia to Mecca, the hajj has become very much a prestige symbol. Every devout Shi'a on the other hand would like to be able to go to Kerbalā, and many do. Meshed and Qum are perennially full of pilgrims. But within easy reach of practically every community in Persia, however small, a shrine of some sort is to be found. If it is actually in a village it will never be empty for long. Even if it is several miles from the nearest village there will always be evidence of attention paid to it. Very often only the name of the holy man, whose reputed tomb the shrine is, is known and often there are variants on this also.

The following is a random selection of shrines in the east and south of Persia:

\section{Khorāsān}

(i) One kilometre to the south-east of Jajarm stands a small dilapidated shrine known by the name of Khājé Mahziyār or 'Ali ibn Mahziyār, of whom nothing is remembered. Although no attempt has been made to repair it for some time, it still fulfils a definite function in the religious life of the district.

(ii) At Kākhk there is an important shrine dedicated to a brother of the Imām Rezā-Sultān Mohammad. This shrine is particularly popular during the three-day festival of Barāt which precedes the birthday of the Twelfth Imām. Coaches bring people from the surrounding district, including Meshed itself. Gypsies and beggars pour in, and the third day culminates in a firework display.

(iii) Baimorgh has a small shrine dedicated to the Imām Rezā.

(iv) Mehné contains the tomb of the mystic Shaikh Abū Sa'īd Abi'l-Khair (A.D. 967-I049), which is used as a shrine.

11 This is an argument frequently offered to prove the superiority of Islam over Christianity. 
(v) Gunābād itself has two shrines: one opposite Mend known as Pīr Kallé, i.e. Pīr va Kallè (the pir and the Head), for legend has it that besides being the grave of a pir the head of Husain's son Qāsim was also buried there.

(vi) The other, known as Dāru'sh-Shafā or Qadamgāh in Deluî, is built over the spot where in an old man's dream 'AlI, the first Imām and son-in-law of the Prophet, was seen to place his foot.

\section{Q $\bar{a}^{\prime}$ enāt}

(vii) At Khor, some 60 miles west of Bïrjand and a veritable island in the north-east corner of the Dasht e Lūt, there is a shrine known by the name of Khājé Nasīr. The shrine is in ruins, and there is no evidence of any attention being paid to it. The people also tell of another shrine having existed there dedicated to a certain Khājé 'Abdullāh, of which no trace now remains. It would appear to be exceptional for a community to have allowed its shrine to fall into complete neglect without having an alternative focus for their religious attentions elsewhere in the vicinity.

The village of Khor is also interesting for the fact that it has a large number of long qanats, popularly said to number seventy-two, all in a state of disrepair and neglect, while the local population occupy themselves almost exclusively with their flocks. No attempt is made at agriculture. Though all admit it would be a rewarding activity in the district, they say they do not know how to cultivate the land. The present population may almost be described as semi-nomadic, the visible village being a base for operations. In the Hudüd al-'Alam Khor is mentioned together with Khūsf (Khūsb) as obtaining its water from qanats, and the wealth of the inhabitants being chiefly in cattle-as early as A.D. 982. It is possible that the shrines were built by a previous generation which also built or kept up the qanats, but no information was available which would suggest a reason for the neglect of both shrines and qanäts, except perhaps that the Ismailis at one time had considerable power in the area. ${ }^{12}$ The fact that the community is of semi-nomadic character may be relevant. Religion is reckoned generally to be less conspicuous among nomads. ${ }^{13}$ However, Fredrik Barth in his book "Nomads of South Persia" mentions that many points along the migration route of the Basseri " are marked with shrines in the form of the graves of holy men. Few of these have any great significance to the nomads, but they usually pray or show respect as they pass by, though they often have no name, and rarely any myth about the actions of the Saint who was buried there. Nor do any of these shrines serve as centres around which large groups congregate. Individuals may seek such shrines for prayers and special requests for help and support from the dead Saint; in the southern areas of winter dispersal are several shrines which are visited by nomads and villagers alike."14

The tribe whose migrational trail passes through the valley of Pasargadae in the province of Färs pay attention to shrines to the extent that on arriving at the tomb of Cyrus they drive their flocks around it three times before passing - in the fashion of the Islamic ritual of tavāf (tawwäf).

The village next to the tomb of Cyrus is known as Mādar e Solaimān-Solomon's Mother-and the local population regard the tomb as that of Solomon's Mother, and treat it as a shrine. There is no other place of religious significance in the area, not even a mosque in the village, and there are no mullās. The people would call themselves orthodox Shi'a. In the months of Ramazān and Muharram, as in most villages, mullās are imported for rōzé-khänī held at the tomb, and outside these months, owing to the lack of any other focus for the people's religious attention, religious activity beyond the set prayers is apparently confined to $d u^{6} \bar{a}$ and weddings at the tomb. The procession on 'Ashura, ${ }^{15}$ headed by the usual 'alam, is once again attracted by the tomb, and like the nomads performs a taväf three times round it. Inside the tomb an Islamic mihräb has been carved and inscribed with the first part of the "Victory" sura of the Qur'ān, and the usual pieces of cloth tied to nails and sticks stuck into the wall abound, tokens of vows. It would appear then that this is a place which has long

\footnotetext{
12 There is a largish ruined fort in the centre of the village.

${ }^{18}$ Since the most conspicuous feature of nomadic life is the migratory routine, the religious routine must be an integral and subsidiary part of this-if it is possible to distinguish between the two.
}

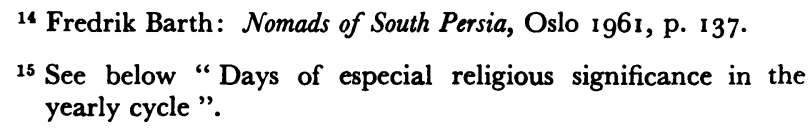


attracted reverence almost irrespective of or separate from, and perhaps previous to, the established religion-though the entry into this context of the Mother of Solomon remains a " mystery ".

(viii) At Khūsf (coupled with Khor in the Hudüd al-'Alam), between Khor and Birjand, a new building has recently been constructed over the old gravestone of Maulānā Mullā Muhammad ibn Hisām (780-870 A.H.), and this is also taking on the functions of a shrine.

\section{Balüchistān-Makrān}

In the south of Balūchistān, the Makrān, although the people are Sunni, there is little outward difference in this aspect of religious behaviour. For instance in Dashtiārī, the eastern part of the coastal plain which stretches across the artificial border into Pakistani Balūchistān, there are two important shrines.

(ix) One of these lies 7 miles from Rimdān, and is dedicated to a Shaikh Portos, an ancestor of Shaikh Cherāgh, the present holy man in the district and the leader of the " setri " sect. ${ }^{16}$

(x) While the other lies some 18 miles from RImdān, within sight of the border, and would seem to be more important. It is dedicated to a certain Shāh Husain, about whom the only information available was that he had been a sayyid.

(xi) In Chāhbahār itself there is a shrine to a certain Ghulām Rasūl, which according to the local people had been built by a group of men from Hyderabad in Pakistan about I Io years ago. Ghulām Rasūl was a sayyid who died at Chāhbāhar on his way to Mecca to perform the hajj, and ordered that after his death a wedding celebration of eight days' duration should be held for him each year on the anniversary of his death, since he had planned to marry on his return from the hajj. This shrine would appear then to have been built and at first controlled by foreigners, in honour of a foreigner. Gradually the festival attracted and included the local population-who are themselves a very motley mixture anyway - and still flourishes, although apparently forgotten in Hyderabad.

(xii)But Chāhbahār also has another shrine, perhaps less imposing in its appearance, but receiving just as much regular attention from the ordinary people. And this is built over a mile outside the town on the point which divides the Sea of Oman from the relatively large bay of Chāhbahār, and it is dedicated to Khezr (Khidrr). It is in fact a qadamgāh. ${ }^{17}$ There are five buildings: (I) a small white shrine approximately $8 \mathrm{ft}$. $\times 8 \mathrm{ft}$. $\times 12 \mathrm{ft}$. high, including the tall, conical dome; (2) an unroofed shrine, covering roughly the same ground area, with a white flag on a pole fixed in the ground to mark the site of the footprint, and a rudimentary mihräb; (3) three mud-brick rooms, described as guest rooms. There is also a semi-circle of stones pointing towards the qibla. This is perhaps the most elaborate Khezr shrine the writer has seen, but smaller shrines are relatively frequent along the coast of the Makrān, and several points are considered sacred to Khezr, though having no building. ${ }^{18}$

\section{Banäder e Färs}

(xiii) Just outside Tāhirī, a village on the beach of the Persian Gulf between Bandar 'Abbās and Kangān, on the site of the ancient Sĩrä, there is a derakht e muräd-deh-a tree that answers prayers. The tree is treated in very much the same way as the more normal shrine. This is the only such tree noticed on the route described above, but there are reports of similar trees from Khorāsān, Āzarbaijān and Māzandarān. They are rendered conspicuous by the pieces of coloured rag tied on their branches, representing nazr. Such trees tend to be explained away now by the invention of saints buried under their branches. There is, of course, a copious literature on sacred trees and theories regarding their

\footnotetext{
16 The "setri" sect appears to distinguish itself from the surrounding Muslims mainly by extra severe seclusion of its women.

17 The place ( $g a \bar{h})$ where Khezr (Khiḍr) placed his foot (qadam).

${ }^{18}$ All the buildings described in the Makrān, and also the mosques in Châhbahâr and Kunārak, appear to owe their
}

style to influences from the Indian sub-continent. The religion too is centred on the eastern side of the Pakistan border. The $z e k r i$ sect has spread from the other side of the border, and most of the remainder of the population acknowledge the primacy of a Shaikh 'Abdullāh in Pakistan. 
origin. It is, however, sufficient here to note the importance of a shrine in the ordinary village community and the things which may be called on to serve the purpose of a shrine in substitution for the more normal pir's grave.

These shrines may be readily classified into six types:

(I) Tombs and places alleged to have some real connection with an Imām or the close relative of an Imām, e.g. at Kākhk and Baimorgh.

(2) Tombs of well-known historical persons, e.g. Abū Sa'īd ibn Abi'l-Khair and Ibn Hisām.

(3) Tombs of comparatively recent and presumably historical persons who had commanded unusual respect in their own communities, e.g. Shaikh Portos and Ghulām Rasūl.

(4) Tombs of Shaikhs and Khājés about whom little or nothing is remembered but who were perhaps once equivalent to type 3, e.g. Khājé Mahziyār, the pĩr in Pīr Kallé, Shāh Husain.

(5) Pre-Islamic shrines or monuments still reverenced by the local population, e.g. the tomb of Cyrus.

(6) Shrines, etc., based on legends and dreams, or a-historical phenomena, e.g. Dāru'sh-Shafā, the shrines to Khezr, and sacred trees.

It is significant that the two examples cited in type I both relate to the Imām Rezā and are situated in the district of Gunābād where the shrine of the Imām Rezā in Meshed owns much property. Types 2, 3 and 4 are comparable and there is little distinction between them. It has been theorized before, that the spiritual trouble with Islam is that it leaves too big a gap between the believer and his God; that this was the attraction of the Imāmate, Șūfi and saint systems, exampled on both sides of the fence -both in the Shi'a and the Ahl e Sunnat. This easy and traditional theory would lead to the conclusion that once the link between God and the believer had been personified locally by a spiritually outstanding man, the shrine grew over the man's grave in preservation of that link. Types 5 and 6 could be explained in the same manner. The memory of the peasantry is notoriously bad with regard to the great men of the past. All ruins come in time to be attributed to Shāh 'Abbās, or perhaps Alexander, Rostam or Solomon. There are scarcely any other candidates. But it is almost the rule for pre-Islamic ruins to retain, or perhaps even improve on the sense of wonder and awe they once commanded, even though the man who built them be completely forgotten. With the course of history their existence becomes a mystery, and once this has happened it is quite a simple step for them to assume the same function as types $I$ to 4 above.

However, this classification does not really concern the function of the various shrines, except perhaps with regard to examples of type I, which in so far as they are linked to, almost subject to, a shrine of universal appeal (e.g. Meshed) attract pilgrims from outside; whereas the religious business of the smaller shrines is confined to $d u^{6} \bar{a}$ and nazr.

One of the corollaries of the importance of shrines in the religion of the Shi'a is the travel which pilgrimage encourages. As far as official Islam is concerned pilgrimage started with the hajj. But in the Shi'a the practice spread on a high level when it was introduced for the shrines of the Imams. The main universal shrines of pilgrimage for the Shi'a are Kerbalā, Meshed and Qum, in that order. Kerbala probably at least equals Mecca in spiritual appeal, if not on the scale of prestige, and is now within the reach of a surprisingly large proportion of the population. Everyone has been to Meshed and Qum. This means travel on a large scale, and although it does not take the believer outside his own culture, it is an important factor in the spread of ideas inside the Muslim world, and inside Persia helps to neutralize the effects of enormous distances and slender lines of communication.

\section{Days of Especial Religious Significance in the Yearly Cycle}

Of the sixteen days of official religious holidays marked in the Persian calendar three occasions are singled out for special attention by the ordinary faithful. Two are celebrations: the 'aid e fetr after 
the fast of Ramazān, and the 'aid e Ghadir Khum, ${ }^{19}$ which justifies the Shi'a interpretation of Islam. The third is 'Áshūrā, the tenth of Muharram and the anniversary of the martyrdom of Husain, and the days leading up to it.

Of these, by far the most religiously significant is 'Āshūrā. The whole of the month of Muharram is a season of mourning, which reaches its climax on the tenth of the month, when, as the Shi'a authorities tell the story, the most shameful and pitiful event of history became fact on the field of Kerbalā. The overriding religious importance of Muharram in the mind of the ordinary believer is proved again and again by the intensity with which it is observed from year to year despite official attempts to restrain it, and the general difference of view between the ordinary man, who makes the occasion live, and the religious class, i.e. not the ordinary mullã, but the religious leaders, which often feels it necessary to hold him in check. This religious class would appear to be particularly worried about ideas and practices which misrepresent the religion they preach. But it seldom happens in the long run that a religious intelligentsia succeeds in shaping or even controlling the religion of the people over whom they sit. Rather the contrary. The religion, in so far as it has any real existence, lives in the ordinary man or woman, who lives unthinkingly and unquestioningly by it. It is for the educated religious thinker to interpret this for his community, and, if he wishes, to rationalize it, not to change it. Government from the top has, however, always been a feature of the Shi' $a$, and this will help to account for any difference we may find between the official and the actual religion.

This year I was privileged to be able to spend the significant days of Muharram in a village of some five to six thousand inhabitants in Khorāsān. By a lucky coincidence restrictions which had been imposed during the last few years were lifted, and the " passion plays" known locally as shbî (= shabih, resemblances, imitations) - the $t a^{6}$ ziye of standard Persian-were once more being performed. In this particular village each of the first ten days of Muharram had traditionally its own shabih. The first few of these did not directly concern the actual Maharram story at all but were, so to speak,introductory. The first play of all, traditionally set for the first day of Muharram, concerns Hazrat e Masih (Christ), and takes place in the time of Qāniyā-an unidentified King of Farang (Europe), who tries to put an end to $\bar{a} z \bar{a} d \bar{a} r \bar{i}$ (the mourning of Muharram), whereupon he sees Christ in a dream. Christ turns away from him, and however much Qäniyā implores, Christ will not look on him as long as he stops the Muslims mourning Husain. This play is particularly moving. The Shi'a are always out to show that they respect Christ and Mary and indeed all the prophets as much if not more than Christians, and further, that Christ was a good Muslim before and after Muhammad. And this play is a justification of the whole Muharram practice-from Christ's mouth! But the educated mulla can find no basis for it in the Qur'ān, the traditions, or histories, and so would rather not have it. What provides the, main bone of contention between the leaders and the faithful in this particular is the actual representation, whether by painting or acting, of religious figures - which is strictly forbidden in official Islam

During the first nine days of Muharram the plays take place in the afternoons and last two or three hours. After sunset in each district of the village someone who can afford it claims the honour of providing dinner - a simple meal, but of the best quality-for the dasté of the district, ${ }^{20}$ prominent residents and the poor. As soon as the dinner is eaten the leader of the dasté sets to chanting a nōhér accompanied by the timed siné-zani ${ }^{22}$ of the dasté. After a time, keeping the same rhythm and continuing the nōhé, they move outside and form a procession before the house with standards ('alam) at the front and rear held by small boys. They then process slowly round the village, stopping outside each of the mosques. Despite the stylization of the ceremony, the intensity with which chests continue to be beaten as late as midnight is impressive, at times almost terrifying and reminiscent of Jung's theory that " when many people gather together to share one common emotion, the total psyche emerging from the group is below the level of the individual psyche ". ${ }^{23}$ Even the little boy on the end of the line who takes advantage of the situation to hit his mate rather than himself is less frequent than would be expected.

19 This is the Persianised form of Ghadir al-Khumm.

${ }^{20}$ Group representing the district in the Muharram ceremonies.

${ }^{21}$ Lament in verse on the tragedy of Kerbalā.

\footnotetext{
22 Beating the chest with both hands.

${ }^{23}$ Jung: Collected works, vol. 9, part I, par. 225.
} 
As it draws nearer to the tenth, the shabih of the day becomes more definitely connected with the Muharram story itself until on the seventh it is the story of Hazrat e 'Abbās, on the eighth of 'Ali Akbar, and on the ninth of Qāsim. ${ }^{24}$

At sunrise on the tenth one is woken by the noise of a crowd running through the alleys carrying the standards and shouting " Yã Husain", summoning the people to the final shabih. Then the dasté of each district forms up and the siné-zani starts once more, having stopped not very many hours before. This brings the time to approximately 8 a.m., and the dastés meet in the maidan-the largest open space available in the centre of the village - and offer a final magnificent chorus of sine-zani. Along one side of the maidän an iwän of shops is decked out in black and coloured materials and rags and is referred to as the "tekyé". ${ }^{25}$ Inside the tekyé on an exalted seat sits the mullā who now reads rōzé. After the rōzé the tekyé serves as a grandstand for the shabih.

By now the greater part of the population is assembled around the maidän, and the nakhl's and 'alam's are brought out. The nakhl is explained as a large similitude of what Husain and his relatives travelled in to Kerbalā. In this particular village there were two, one measuring approximately $12 \mathrm{ft}$. $\times 8 \mathrm{ft}$. $\times 8 \mathrm{ft}$. high, the second slightly smaller. They have been waiting just out of sight of the maidān. Two small boys perched on top shout "Yā Husain, yā Husain ", while thirty to forty fullgrown men station themselves round the sides, lift it and carry it at a trotting pace towards the maidan, turning about on themselves twice on the way. On reaching the maidān they make a taväf three times round the dastés standing in the centre and finally settle somewhere on the outside. The dastés then form themselves into large circles and accompany the nōhe of the leader in the middle by beating their chests and moving one step to the right with each beat. As with all forms of siné-zani and nōhé there is a refrain in which all join. The whole gives the impression of a controlled mystic dance and forms an emotionally effective ritual. By 9 a.m. the centre of the maidon was clear again, the drums ( $t a b l)$ beat and the final shabih began. This, the final day, covered the whole Muharram story and continued non-stop for four hours in the hot sun until I o'clock.

When it ended the nakhl's were raised again, rushed round the maidän several times, and away. Finally, the people adjourned outside the town to a small shrine. The climax was over, and the evening was spent in quieter and less energetic mourning for those of Husain's family widowed and orphaned by the event. ${ }^{26}$

\section{The Life Cycle}

The only stage of life of truly religious significance is puberty, which is the qualification for religious responsibility, but it is not marked by any ceremony. The stages which are in fact marked in the religion are circumcision (khatné), betrothal ('aqd), wedding ('arüsi), and death, of which the first three are occasions for celebration and the last for mourning and division of property.

Circumcision takes place normally between the ages of 10 and 12, and may be marked with festivity, including music and dancing, and presents for the sufferer. But the only reason adduced for it is that it is desirable ${ }^{27}$ from the point of view of the religious law, and from the point of view of cleanliness.

Betrothal may take place any length of time before marriage and at any age, and is technically more important than 'arūsi. Between betrothal and marriage the man is expected to visit the girl every evening. The man will normally be somewhat older than the girl, and it is normal for the girl to marry well before the age of 18 . Divorce is a matter of still less religious significance. It is, in fact, the religion which provides the basis for its facility. Any problems it involves are usually material since it requires the payment of the mehriye or marriage portion which was settled on at the time of betrothal. It is perhaps surprising at first how much importance is attached to a girl's virginity before marriage and to the chastity of women in general, when so little importance is attached to divorce.

\footnotetext{
24 The step-brother and two of the sons of Husain respectively.

${ }^{25}$ Literally a place of repose, used with the meaning of a

temporary place of worship. In the villages around Lasht $e$

Neshā mihräbs were not built into the mosques, which were for

this reason termed tekye instead of masjid.

26 Shām e gharỉbān.

27 Mustahabb.
} 
Sex, however, is accepted as indispensable to normal life, both for men and women, and since the society is orientated round the man, the marriage contract is concerned with the pleasure, convenience and freedom of the man rather than the woman. For marriage is first and foremost a contract, and if it later becomes in practice a partnership this is lucky or rather through force of circumstances, though of course not rare. There is no mystical union.

\section{The Evil Eye}

Intimately linked with the conception of sin and evil in day-to-day life is the chashm e shür-the salt or evil eye-that which, the saying goes, only the chashm e naz - the fond eye-is more dangerous. For it is mostly unconscious envy that harms. It is sometimes considered to be an unconscious property of certain people, particularly persons with green eyes.

The evil eye is a concept which has attracted much interest and scholarship in various parts of the world. The fear of envy becomes exaggerated into the fear of praise: The following will serve as not untypical examples in Persia:

(I) A newly married girl returned from Europe with her four-month-old first baby to stay a few months with her village-bred mother in Tehran. The baby was pretty, and the young mother, having spent some time in Europe, dressed it in very pretty clothes. The grandmother, however, insisted that it should be dressed almost in rags, so that visitors should be less likely to notice that it was pretty and it would be less likely to attract the evil eye.

(2) In one of the villages of Gunābād a daughter returned to stay with her mother after a long absence. One by one the women of the village, according to custom, came to visit the new arrival. After their departure the mother, who is terribly fond of her daughter and therefore fears the evil eye, must take precautions. If one of the visitors praised the daughter or said how well she looked, the precautions would be all the more necessary. Perhaps one or two women in the village will even have the reputation of having chashm e shür.

The normal precautions are twofold, of which either one or both may be taken:

(I) Espanj-wild rue-may be burnt, and the room filled with the odour thus produced.

(2) Zamé-rock alum-may be burnt. As it burns it is said to take on the appearance of an eye. Its ashes are poured into water and the water into a running stream.

The person who fears the results of the evil eye never takes the precautions in person. Normally a poor woman is chosen to do it-her performance of it may be reckoned to be particularly efficacious, ${ }^{28}$ or she may be a sayyid - so that a savāb is to some extent entailed.

The custom of giving shirini-sweetmeats-to all visitors on various occasions, including moving to a new house, passing an examination, any sort of personal success, etc., most likely originates in fear of the evil eye. Similarly, formulas like In shä'alläh which are designed to avert the slightest opportunity for Nemesis.

\section{Conclusion}

We wish here to point out a certain dichotomy in the religious life under study, as it appears from the observations set out above. We may perhaps make this clearer by exaggerating the definition of the two strains.

On the one hand is what we shall call the official religion, ${ }^{29}$ which would appear to be in a state of being continually exported by the movement of mullās and pilgrimage from the great urban centres of religious thought and education into the general village life. It is a religion in the practice of which the all-important principle is that of the golden mean. It contains rules of ritual prayers, fasting, celebration, mourning and general conduct, which concern the will rather than the heart (in their 
common interpretation). That is, they require in the first place an act rather than an attitude. And in so far as an attitude is produced in the believer by the performance of these acts it is this:

(I) a ready awareness of the unchanging, omnipotent, separate unity of God, who is responsible for everything except the actual decisions of our own free will;

(2) below the station of Imām and Prophet a definite feeling of equality with and independence of all conditions of one's fellow men before God.

This feeling of detachment (outside the personal relationship pattern already outlined) from one's fellow men is an integral part of the social order, whether that social order be viewed as a religio-social equality before God, or a politico-social equality before the Shah.

Ramazān provides a useful example of the general moral standpoint of the official religion. The faithful are commanded to refrain from allowing anything to pass their lips for roughly half of each twenty-four hours throughout one month of the year. And the reason: everything they have is the gift of God's bounty: acknowledge this bounty by freely refraining from the use of these gifts for half of each day for just one month per year. This surely is a religion of moderation.

The conception of the evil eye fits well into this pattern. Sin tends to be regarded as a form of misfortune of almost unaccountable origin. Success is dangerous. So, almost, one feels, is unusual virtue. The danger of this conception is that it stands in the way of social and spiritual progress. We might almost dare to say that it combats the evolutionary urge.

The second strain is more difficult to define. To determine its origin would be outside the scope of this article, for it would require an investigation into the syncretic residue of all the creeds which have passed through Persia in the course of her history. We may, however, conveniently label it the religion of the shrine, as distinct from the religion of the mosque. The following aspects of it may be noted:

(I) Instead of a standard equality it is characterized by a hierarchy, the stages of which are not very well defined, from the ordinary man through holy men, the Imāms and Prophets to God. This is also paralleled on the politico-social side, where side by side with the theoretical position of general equality before, and therefore access to, the Shah (which may still be made use of), there exists for the convenience of everyday life a hierarchy, the stages of which are likewise not clearly defined, since social position depends so very much on personality and personal relationships. To bridge the gap to God the station of the Imāms is exaggerated. To counteract this, in the official religion it is noticeably played down.

(2) Sin has a different quality. For even without its burden the believer feels the need of comforting grace from the higher echelons of the hierarchy, whereas in the official religion grace, unless it be the inalienable property of the Imäms, is not known.

(3) While the religion of the mosque denies the power of fate in a man's choice of action, the religion of the shrine scarcely credits the will with any free choice of its own.

These distinctions which we have made are artificial to the extent that nowhere does one strain exist independently of the other-not even in the centre of the most sophisticated urban community. The religion of the rural community will always support the organized religion of the towns, given occasion. And it is, of course, the official religion which is the conscious religion. The ordinary man is conscious first and foremost of his "muslimness". The second strain we have identified is quite unconscious in so far as it is distinct. Nevertheless, the theoretical contradiction is there and the distinction may be outlined on paper.

The real business of day-to-day spiritual life is performed at the occasional rōze-khāni, and at the local shrine as required by means of $d u^{6} \bar{a}$ and nazr. While the official religion provides unchanging rules for the unchanging spiritual world of Islam, the rözé-khāni focuses the attention on a past event and aims at renewing faith by evoking sympathy for the sufferer in that event. According to the official view, Husain was killed because he did what his duty required him to do. He might have been 
successful, he might not. In fact, he was not. He was killed in such pitiful circumstances without wavering in the least from what he knew to be his duty, that we like to remember him and the event in this way over and above all the other Imāms and their works. For the ordinary believer, however, attendance at a rözé-khäni and the artificially induced, vocal sympathy for Husain and his companions in their fate has taken on an almost sacramental value. But this, instead of being directed, is ignored and discounted by the official religion and remains an event in the past with no religious use made of it. The most important event of the Shi' ${ }^{6}$ year is an occasion for straight mourning.

In the popular religion the elements of spirituality which a psychologist of the Jungian school would consider necessary for the healthy life of a western community (in its integration with its a-temporal "collective unsconscious") are probably distinguishable and exist within the framework of the official religion, yet the official religion treats them as a series of rules (God-given, it is true) and historical facts and tries to keep them so. It does not unite theminto one spiritual system independent of history, or allow them to become mysteries, but leaves them isolated and unexploited in the mind of the ordinary believer. Shi'ite Islam, while claiming to be a universal religion has not seen fit to universalize the particular in its doctrines.

Nevertheless, the system lives. It is-and this is one of its major claims in its dialogue with Christianity - a rule of life by which it is possible to live and which has been lived by without essential change for many centuries. It demands a certain amount of time and even thought per day and in return provides spiritual comfort and security. For the uneducated enquiring mind it explains everything apparently very logically, proves itself the true religion, fixes the social order, gets him up early in the morning, marks noon and sunset, shows him the middle way through life, while allowing him a decent amount of latitude in following it.

Once he has set his foot outside this middle way, there is no conception of atonement because of the distance between man and God, and the only way of regaining his lost place in paradise is to attract the attention of the Imāms-particularly Husain-by pilgrimage and rōzé-khāni, who will then be expected to intercede.

The function of such a religion is positive only in so far as it enframes and conserves the social status quo, sanctions and to a large extent provides the rules by which the community lives as a community. And it does provide hope for the believer to live by. On the negative side however, there is this, that the only incentive provided concerns the individual personal relations between the believer and the Imāms. In the progress of the community as a community it has no direct interest. ${ }^{30}$

so It must be remembered that throughout this article we have been concerned only with the religion as generally practised in the areas we have visited, and not with its ideal form. 